\title{
The Social Construction of Community Care
}


Also by Anthea Symonds (with Sheila Hunt) and published by Macmillan

THE SOCIAL MEANING OF MIDWIFERY

THE MIDWIFE AND SOCIETY: Perspectives, Policies and Practice 


\section{The Social Construction of Community Care}

Edited by

Anthea Symonds

and

Anne Kelly 


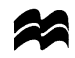

Selection, editorial matter, part introductions and summaries

(C) Anthea Symonds and Anne Kelly 1998

Foreword (C) Jan Walmsley 1998

Chapters 1-4 (C) Anthea Symonds 1998

Chapters 5 and 6 (C) Anne Kelly 1998

Other chapters (in order): (C) Nancy Harding; Stephen Clarke; Tim Stainton; Irene Webber; Anne Kelly, Gaynor Mabbett and Renata Thomé; Pat Davies; Robert F. Drake; David Rea; John Wilkinson; Mark Drakeford;

Matthew Colton, Charlotte Drury and Margaret Williams;

Julia Johnson and Bill Bytheway; Robert F. Drake; Ken Blakemore 1998

All rights reserved. No reproduction, copy or transmission of this publication may be made without written permission.

No paragraph of this publication may be reproduced, copied or transmitted save with written permission or in accordance with the provisions of the Copyright, Designs and Patents Act 1988, or under the terms of any licence permitting limited copying issued by the Copyright Licensing Agency, 90 Tottenham Court Road, London W1P 9HE.

Any person who does any unauthorised act in relation to this publication may be liable to criminal prosecution and civil claims for damages.

The authors have asserted their rights to be identified as the authors of this work in accordance with the Copyright, Designs and Patents Act 1988.

First published 1998 by

MACMILLAN PRESS LTD

Houndmills, Basingstoke, Hampshire RG21 6XS

and London

Companies and representatives throughout the world

ISBN 978-0-333-66298-4

ISBN 978-1-349-14107-4 (eBook)

DOI 10.1007/978-1-349-14107-4

A catalogue record for this book is available from the British Library.

This book is printed on paper suitable for recycling and made from fully managed and sustained forest sources.

$\begin{array}{lllllllll}10 & 9 & 8 & 7 & 6 & 5 & 4 & 3 & 2\end{array}$

$\begin{array}{lllllllll}07 & 06 & 05 & 04 & 03 & 02 & 01 & 00 & 99\end{array}$ 
To all those who are living in and for the community 


\section{Contents}

List of Figures $\quad$ x

List of Tables $\quad$ xi

Foreword by a fan Walmsley xii

Preface xiv

Notes on the Contributors $\quad \mathrm{xv}$

PART I THE SOGIAL CONSTRUCTION OF THE REALITY OF COMMUNITY GARE

Introduction 3

1. Social construction and the concept of 'community' 7 Anthea Symonds

2. The social construction of public care: from community care to care by the state

Anthea Symonds

3. The social reconstruction of care: from the state to the 'community'

Anthea Symonds

4. Care for the community: inmates, patients, consumers and citizens

Anthea Symonds

Part I: Summary

\section{PART II PROFESSIONS AND A GHANGING WORLD}

Introduction 75

5. Concepts of professions and professionalism 78 Anne Kelly 
viii - Contents

6. Professional and the changed environment Anne Kelly

7. The social construction of management Nancy Harding

8. Community development and health professionals Stephen Clarke

9. Rights and rhetoric of practice: contradictions for practitioners

Tim Stainton

10. Professions and school nursing Irene Webber

11. Professions and community nursing Anne Kelly, Gaynor Mabbett and Renata Thomé

12. The community psychiatric nurse and primary health care

Pat Davies

13. Professionals and the voluntary sector Robert F. Drake

Part II: Summary

\section{PART III GARE FOR GOMMUNITIES}

Introduction

14. The myth of the market in the organisation of community care

David Rea

15. Danger on the streets: mental illness, community care and ingratitude

John Wilkinson

16. Poverty and community care

Mark Drakeford

17. Working with children in need under the Children Act 1989

Matthew Colton, Charlotte Drury and Margaret Williams

Bill Bytheway and Julia Johnson

19. Housing and older people 
Contents · ix

20. Working with minority ethnic communities Ken Blakemore

Part III: Summary

References

Index

305 


\section{List of figures}

4.1 Percentage of weekly household income from salaries, benefits and pensions, 1965 and 1995

5.1 Composition of NHS workforce, 1981-90 88

5.2 Numbers of different occupations in the NHS in England in $1990 \quad 88$

15.1 Newspaper linkage of 'community care' with violent death 212 


\section{List of tables}

2.1 Important landmarks of state measures and concern before $1945 \quad 30$

2.2 Important milestones in voluntary provision before $1945 \quad 31$

2.3 Professionalisation of health and social care to the community before 1945

3.1 Fordism and post-Fordism 34

3.2 Characteristics of markets and quasi-markets 44

$\begin{array}{lll}3.3 & \text { Elements in opposition and in coexistence } & 47\end{array}$

3.4 Landmarks in state provision and concern, 1945-79 48

3.5 Landmarks in voluntary provision, 1945-96 49

3.6 Landmarks in state provision, 1979-96 50

4.1 Social reality and delivery of Community care 51

4.2 Number and proportion of employees with gross earnings

$\begin{array}{lll}4.3 & \text { Dialectical relationships in care provision } & 63\end{array}$

$\begin{array}{lll}4.4 & \text { State policies and children } & 67\end{array}$

4.5 State policies and disability 68

$\begin{array}{lll}4.6 & \text { State policies and older people } & 70\end{array}$

5.1 Euphemistic community care discourses $\quad 80$

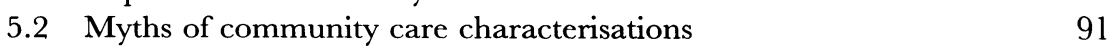

6.1 Policies of the last two decades which have shaped professional services for community care $\quad 103$

$\begin{array}{ll}\text { 6.2 Landmarks for professional practice development } & 108\end{array}$

7.1 Presumed differences between public and private sector $\begin{array}{ll}\text { management } & 114\end{array}$

$\begin{array}{lll}10.1 & \text { Rate of pregnancies } & 143\end{array}$

15.1 Codes of alternative meanings in social care language 215

19.1 Elderly people and housing by tenure, $1991 \quad 255$

19.2 Institutions - provision for older people (England), 1994-5 256

20.1 Ethnic composition of selected areas of the United Kingdom, $1993 \quad 265$

20.2 Proportions of each ethnic group in selected areas of the United Kingdom, 1993

20.3 Country or area of birth of all persons born outside the United Kingdom, 1991 


\section{Foreword}

I am pleased to write the Foreword to what is an important contribution to a much used, much discussed, much debated term, community care.

Since at least 1601, when the Elizabethan Poor Law came onto the statute book, the state has formally accepted some responsibility for the poorest, most needy members of the community, when they or their families cannot support them. Yet who deserves help, how it should be provided, how it should be paid for, organised and distributed, and the balance between public and private responsibilities have been questions which have had different answers at different periods of history. Community care has been one way of answering these questions. But historical and sociological research shows that community care is at one and the same time a description of people's everyday experience of life, 'a euphemism for women's labour in the home' and a distinctive range of professional practice (Bornat et al. 1993: xi). Whilst carrying the 'rosy glow' of the caring community, it has also been used as a cheaper means of control than institutional care, but equally coercive and excluding in its practice (Thomson 1992). Community care is also shorthand for the legislative framework within which health and social care services have been delivered since 1990. But what it is and what it should be, remains opaque. It has been used by governments of different political persuasions to convey what are often opposite meanings (Baldwin and Hattersley 1991), it is a concept which is overladen with myths, preconceptions and assumptions, and has become in popular discourse a code word for chaos and danger on the streets (Wilkinson, this volume Chapter 15).

Hence the timeliness and significance of this book, a volume which will assist academics, students and practitioners in making sense of great changes in the location of care provision, in the values and practices of care providers and users, and in the whole culture of health and social care which contemporary community care reforms signify. The book's contribution to unravelling the mysteries of community care is not to do the impossible - provide a once and for all definition. Rather, its approach is to examine how, through the building and interweaving of sets of ideas, present community care policy and practice have been constructed.

In the four chapters which constitute Section One of the book Anthea Symonds sheds light on a much neglected area, the history of community care. Showing a rare mastery of developments in both health and social care she demonstrates that the apparently inexorable march towards the present community care framework has in fact been comprised of a patchwork of contradictory 
impulses and motives. The present reality, she demonstrates, is full of promise and full of problems: the promise of 'empowerment' for 'citizen consumers'; the problems of containing aspirations in a system already under administrative and financial strain.

The community care policies of the 1990s were not a fresh start, but imposed on long established and apparently powerful groups of professions, semi-professions and voluntary organisations. Hence some of the struggles over competing definitions of community care, what it should mean, what it does mean, and how it should be managed and organised. The impact of community care on these groups, and their responses to it are the subject of Section 2 of the book. Alongside rather depressing analyses of the constraints imposed by public sector management strategies and financial stringency, the reality behind the rhetoric of empowerment, come some grounds for optimism. Professionals, on the whole, recognise it as their duty to provide care, despite the constraints. Some are finding ways of combatting the often divisive individualism implicit in the community care reforms through developing working alliances with communities they are trying to serve. There remains a place for the positive ideals of professionalism, altruism, an ethic of care and a sense of justice within the changed and changing culture.

Community care is not just about policies, or about paid workers, it is also about people in need. A watch word of the third section of the book is diversity. The community care reforms were about creating diversity - of providers, of provision, of practice. A diverse population, it was argued, needed, not monolithic unresponsive and hidebound services, but choice, consumer power, autonomy. The metaphor for this cultural shift in the terminology of the New Right, was the market. A market could deliver where the welfare state had failed efficiency, economy and effectiveness. But, like community care itself, the market is a metaphor. Completely free and untrammelled markets are no less a figment of the imagination than true equality. More than most, the market in community care is constrained. The aim is not to stimulate demand, but to contain it. The customers are not the end users, but the purchasers. Many of the intended beneficiaries of the market are amongst the most powerless and least informed members of society. They are also, overwhelmingly poor. It is against this background that the contributors to the third Section of the book write. They raise important questions about the viability of community care when communities are themselves impoverished, the conceptual language available to conceptualise their situations is limited, and the services which are intended to support them are under-resourced.

Sadly, it seems probable that the higher ideals of community care, the aspiration to give people who need care dignity, autonomy and choice, are unlikely to be realised for many in the immediate future. But this book will be an inspiration and an illumination to those involved in the struggle to realise those ideals in the testing times ahead. 


\section{Preface}

The 1990s have seen a revolution in the provision of health and social care in Britain; a system of beliefs, practices and expectations which has been in existence for over fifty years has been turned upside down. The basic premise of this book is that the concept of placing care for certain groups of people within the location of a 'community' is one which is loaded with contradictions and complexities for both professional health and social care providers and for people in receipt of such care.

The book is in three parts; Part I sets out the social construction of the provision of care delivery social policies; Part II focuses upon the professional, managerial and informal and voluntary sector responses to changing policy direction; Part III concentrates on the underlying demands of a truly needs-led service.

The idea of community care is far more than merely a change in the site and location of care provision; it signals a change in values, occupational practices and assumptions. Whole traditions of professional beliefs and practices must be altered, and so must the expectations and realities of users of services. It is above all a cultural change.

Running through all three parts in the recurring theme of the all-embracing nature of this change. Part I looks at the historical development of health and social care provision via social policies and also attempts to pose a sociological understanding of the structures and processes of British society within which these policies were enacted. Part II looks specifically at the present and future roles of health and social care professionals and the voluntary sector in the delivery of community services within a mixed economy of care. Part III addresses the underlying needs of vulnerable groups of users in the 'community' and the necessity for professionals to develop new ways of working with those living in poverty and need.

Overall this book seeks to 'push' practitioners and students into questioning their preconceptions and into constructing new and effective means of practising real care for the community.

ANTHEA SyMONDS

ANNE KeLLY

Note: the editors and publishers are grateful to The Independent newspaper for permission to use the illustration on page 212 . 


\section{Notes on the Contributors}

Ken Blakemore has written extensively on race relations, the ageing of Britain's black and Asian communities, and on other policy issues closely related to community care. He has recently co-authored a study of equal opportunity policies and is currently collaborating with Anthea Symonds to prepare a book on the sociology of health and illness for nurses.

Bill Bytheway is Lecturer in Sociology at the University of Wales Swansea. He edits the journal Ageing and Society and is a research fellow at the School of Health and Social Welfare at the Open University.

Stephen Clarke is Lecturer in Applied Social Studies at the University of Wales Swansea. He has practised and taught community development for many years in Britain and in southern Africa. He is the author of Social Work as Community Development.

Matthew Colton is Senior Lecturer in Applied Social Studies at the University of Wales Swansea. He has published widely and is a member of the Executive Committee of the European Scientific Association on Residential and Foster Community Alternatives: International Journal of Family Care and the International Journal of Child Welfare.

Pat Davies works as a research nurse in mid-Wales. She is qualified as a psychiatric nurse and has worked as a lecturer in nursing. Currently she is studying for a $\mathrm{PhD}$, and is specifically interested in the effect of prescribed courses on nurse education.

Robert F. Drake is Lecturer in Social Policy at the University of Wales Swansea, Associate Lecturer with The Open University, and Honorary Research Fellow at the University of Wales Cardiff. He has published widely and is currently engaged in writing a book on contemporary disability policies.

Mark Drakeford works at the School for Social and Administrative Studies at the University of Wales Cardiff. He teaches social policy and social work, having particular interest in poverty and social exclusion. He has previously worked as a probation officer and community development worker on the Ely estate in Cardiff. 
Charlotte Drury is a researcher at the Department of Social Policy and Applied Social Studies, University of Wales Swansea. Her main interests lie in evaluative and research studies in the field of child care, and working with adult survivors of child sexual abuse. She is co-author of Children in Need and Staying Together.

Nancy Harding teaches health management at the Nuffield Institute for Health at the University of Leeds. She is the co-author of the forthcoming book, Confused Professionals: The Social Construction of Dementia, and is currently working on another, The Social Construction of Management.

Julia Johnson is Lecturer at the School of Health and Social Welfare at the Open University. She is also co-editor of Ageing and Later Life.

Anne Kelly is Lecturer in Health and Community Services Management at the University of Wales Swansea, where she previously had substantial experience as Director of the Community Health Nursing Course. She has been a member of the Health Visitors' Joint Committee of the United Kingdom Central Council, for Nursing, Midwifery and Health Visiting, the Welsh National Board for Nursing, Midwifery and Health Visiting, and the Professional and General Purpose Committee of the Health Visitors' Association.

Gaynor Mabbett fulfilled a clinician role in general medical wards and coronary care before pracctising as a district nurse. Her career in nurse education began in 1986. Since 1993 she has had a lead role in the district nursing component of the Diploma in Community Health Studies course at the University of Wales Swansea.

David Rea teaches at the Institute of Health Care Studies, University Wales Swansea. He has previously taught at the Universities of Plymouth, Huddersfield and Brighton. His research interests include the behavioural aspects of financial management in health care organisations and the development of social markets.

Tim Stainton is Lecturer in Social Policy and Applied Social Studies at the University of Wales Swansea. He has worked in the practice, policy and research areas of community care with a particular interest in learning disability and disability rights. His book Autonomy and Social Policy sets out a theory of rightsbased policy for community care.

Anthea Symonds is Lecturer in Social Policy at the Department of Social Policy, University of Wales Swansea. She has written extensively on the female professions of midwifery and health visiting She is currently researching the effects of policy changes on community-based practice and the potential of anti-poverty strategies to improve health care services. 
Renata Thomé has a background in general nursing, children's nursing and health visiting. She was appointed as Lecturer with the University of Wales Swansea in 1991. Since then she has pursued interests in primary care and community nursing developments through working as course coordinator for the first Nurse Practitioner Diploma course to be set up in Wales.

Irene Webber is Lecturer in Nursing at the School of Nursing Studies, University of Wales College of Medicine, Cardiff. Her particular interests are children's nursing, child family health care, primary health care and ethical issues in nursing.

John Wilkinson wrote his contribution to this book while he was Staff Development and Training Officer for the West Glamorgan Mental Health Strategy, which was a joint health, social services, voluntary sector and academic post funded by the Welsh Office. He is currently Mental Health Commissioner in the Department of Public Health, East London and the City Health Authority.

Margaret Williams is Assistant Professor, Faculty of Social Work, University of Calgary. Her major interest lies in evaluative and research studies in the field of child care. She has published widely and is co-author of Children in Need and Staying Together. 